\title{
ADULT AND IMMATURE CALVERTIELLIDAE (INSECTA: PALAEODICTYOPTERA) FROM THE UPPER PALEOZOIC OF NEW MEXICO AND CZECHOSLOVAKIA*
}

\author{
By JaRmila KuKalova-PeCK ANd Stewart B. PeCK \\ Departments of Geology and Biology, Carleton University \\ Ottawa, Ontario K1S 5B6, Canada
}

It is generally agreed that insects have been abundant since the Upper Paleozoic. However, occurrences of fossil insects in the Upper Carboniferous and Permian are quite rare, mainly because of the scarcity of deposition sites. Especially rare are localities that yield a diverse and well preserved assemblage sampling a large community. This is regrettable since the insects, through their enormous dispersal potential and rapid evolution, are well suited for paleobiogeographical studies, especially for comparisons on an intercontinental level. It is assumed that Paleozoic plants and insects coevolved through a close and mutual association, and that this interaction, on all levels of development, was of fundamental importance in directing evolutionary trends. Hence researches on fossil insects and plants complement each other and hold great potential for paleogeography, paleoclimatology and stratigraphy of the Upper Paleozoic, as well as for theoretical evolutionary studies in both groups.

On the entire North American continent there are at present only two localities which have yielded a rich and diverse fossil insect fauna comparable to the best Paleozoic localities of Europe and Asia: Mazon Creek, Illinois (Middle Pennsylvanian deposits equal to Westphalian C-D of the European divisions), and Elmo, Kansas (Lower Permian deposits). Concerning potentially promising regions, the Upper Paleozoic strata of New Mexico have attracted the attention of specialists in the last decade through random discoveries of fossil insects (8 specimens from the Manzanita Mountains, SE of Albuquerque, and one specimen from Santa Fe Creek, Santa $\mathrm{Fe}$ ). Those fossils suitable for description were treated by Carpenter (1970). Since the North American West is important in spanning the gap in paleobiogeographical knowledge of the

*Manuscript received by the editor May 20, 1976. 
Paleozoic entomofauna, there is a need for a systematic search for new localities in New Mexico and other western states.

In the summer of 1975 we searched for insect fossils in the Manzanita Mountains, in a clay pit SE of Albuquerque, on New Mexico highway 10 (14 on some maps). In these deposits, presumably of late Pennsylvanian (Virgilian) age, five insects had previously been found by the paleobotanist Dr. S. Mamay (U.S. National Museum, Washington) and three were discovered by students of the Department of Geology, University of New Mexico, Albuquerque. We found 20 additional specimens but neither the composition of the insect assemblage nor the state of preservation was good enough for detailed study and the deposit was judged not worthy of extensive excavation. The material was redeposited and composed almost entirely of more resistant fragments of wings and of cockroaches, the tegmina of which are too variable in venation to be useful for taxonomic purposes.

However, on the same trip, during a visit to the University of New Mexico in Albuquerque, Dr. Barry Kues, Department of Geology, showed us and generously loaned interesting material that he found in Carrizo Arroyo, Valencia Co., about 22 miles $\mathrm{SW}$ of Albuquerque. The small but promising collection consists of two well preserved wings of Palaeodictyoptera (Calvertiellidae and Syntonopteridae), two Protorthoptera, and several Blattodea. The age of the Carrizo locality, judging from the plant fossils, is estimated as late Pennsylvanian (Virgilian), and this is close to the age of the two major European insect localities; the late Carboniferous (Stephanian) locality of Commentry, France, and the early Lower Permian (Upper Autunian) locality in Obora, Czechoslovakia.

This paper is concerned wit the Palaeodictyoptera of the advanced family Calvertiellidae from New Mexico and from Czechoslovakia. The most notable character of the family is that many features of wing venation are suggestive of the Odonata: the simulated arculus, the "subnodal" cross veins, the general arrangement of the vein pattern, the serrated costa, the odonatoid character of the reticulation, the corrugation extended by intercalated sectors, the tendency to fuse $\mathrm{R}+\mathrm{M}$, the suppression of the $\mathrm{CuA}$, and the development of simple, parallel and curved anal veins (Tillyard, 1925; Carpenter, 1943; Kukalova, 1955, 1964; Kukalova-Peck, 1974). These features do not indicate an immediate phylogenetic relationship with 
Odonata, but are expressions of a genetically based "latent homology" (sensu de Beer, 1971); they occur independently and to lesser extent throughout the Paleoptera.

The family Calvertiellidae has previously been known only from the separated single fore and hind wings of adults. This paper describes the fore wings of a young nymphal instar and of a subimago from the Lower Permian of Obora, Czechoslovakia, and the hind wing of an adult from New Mexico, and briefly discusses the ontogenetic development of Paleozoic nymphs.

Concerning stratigraphy, the calvertiellids are distributed throughout Lower Permian strata; Moraviptera recticulata Kukalova was found in very early Lower Permian and Moravia convergens Kukalova in early Lower Permian in Czechoslovakia, and Calvertiella permiana Tillyard in late Lower Permian of Kansas. The specimen described here as Carrizala arroyo $\mathrm{n}$. g. and $\mathrm{n}$. $\mathrm{sp}$. is the oldest known representative of the family, from the late Pennsylvanian of New Miexco. An attempt is made to identify those wing characters which tend to change successively with time, and to distinguish them from features which are more independently variable.

\section{Adults and Pre-adults of the Calvertiellidae}

Adult wings of Paleozoic Paleoptera have a straight or almost straight anterior margin and are held at right angles to the body. The nymphal wings are easily distinguishable by the characteristic "nymphal bend" at which the wing axis is turned more lateroposteriorly by the convex curvature of the anterior margin and the concave curvature of the posterior margin (figs. 1, 3, 4, 8). The wing bend was mentioned as occurring in Megasecoptera (Carpenter and Richardson, 1969; Kukalova-Peck, 1974) but was also present in Ephemeroptera (Kukalova, 1968, see figures) and in Palaeodictyoptera (Sharov, 1971, see figures; Wooton, 1972, see figures). It was probably also present in the still unknown nymphs of Paleozoic Odonata. During an individual's ontogeny, the nymphal bend becomes successively straightened (figs. 4A and B, 8) with each moult until it has completely disappeared in adult wings (figs. 2, 4C). In Megasecoptera as well as in Ephemeroptera, the nymphal bend is located in the proximal third of the wings (Kukalova, 1968, see figures; Carpenter-Richardson, 1969, see figures; KukalovaPeck, 1974). In the calvertiellid Palaeodictyoptera and apparently 


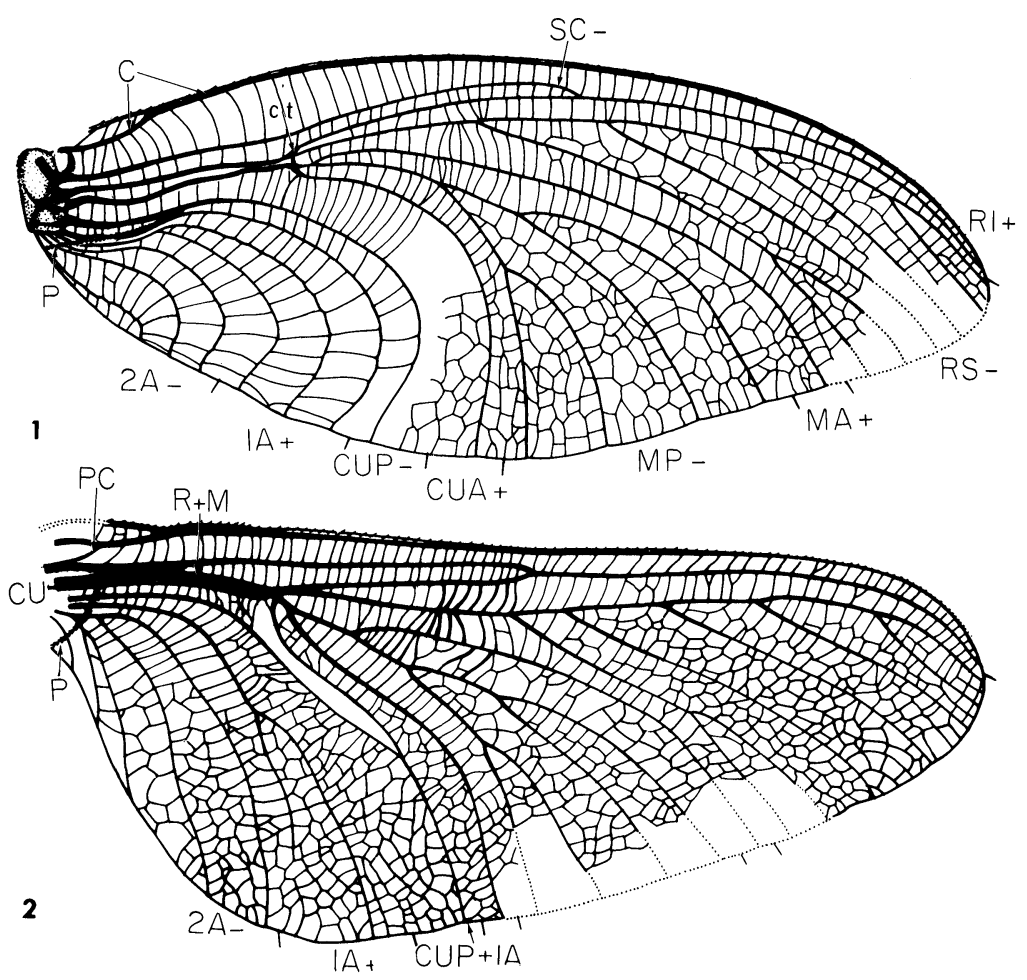

Fig. 1. Moravia convergens, subimaginal fore wing with highly convex anterior margin and narrowed wing tip. Lower Permian of Czechoslovakia. Original. P anal brace.

Fig. 2. Carrizopteryx arroyo, n. sp., adult hind wing. Late Upper Carboniferous of New Mexico. Holotype. PC - postcostal vein; $\mathrm{P}$ - anal brance.

in many other nymphs with basally broad wings, the nymphal bend is limited to the distal half of the wings (fig. 3; Wootton, 1972, see figs. 1 and 2). During ontogeny, the bend is progressively shifted more distally in the older nymphal instars and in the subimagos (figs. 4A and B), until it is absent in the adult moult (fig. 4C). Thus, the angle of attachment to the body, as well as the outline of the anterior and posterior margin of the wings, changes successively and fluently, as indicated. 
The nymphal wings in the Paleozoic insects are veined, articulated to the notum by pteralia, movable, and are generally considered to be functional (Sharov, 1957, 1966, 1971; Carpenter and Richardson, 1969; Kukalova, 1968; Wootton, 1972). The nymphal bend occurs only in those of the Paleoptera, the wings of which are phylogenetically bound both to be oriented laterally and to lack the ability of being flexed backwards over the abdomen. Nevertheless, the nymphal bend itself is not phylogenetically based in Paleoptera, but is adaptive. It is an alternative solution towards gaining the advantage of wing flexing, with the result that the developing wings do not impede as much the forward movement. This developed through an independent adaptation process which took place mainly in the young pre-adults (nymphs) and has nothing in common with the paleopterous or neopterous condition in the phylogenetic sense of these terms.

According to abundant fossil evidence, the fact that the immature stages of the ancestors of modern pterygotes had not solid but articulated and functional wing pads is completely contradictory to the validity of the paranotal theory, which derives the wings from the solid lateral notal expansions of the apterygotes. Were the paranotal theory correct the apparent paradox arises that the ancestral forms had hinged and complexly movable pads, while the descendants fell back to having "primitively" firmly attached wing pads, giving witness to their origin from paranota. However, the wing pads of modern nymphs were clearly secondarily immobilized and fused with the lateral margins of the terga. This adaptive process led to the more distinctively dimorphic condition between the pre-adult and adult stages in modern insects. The nymphal wing pads never had anything in common with paranotal expansions.

\section{Moravia convergens Kukalova, young nymph}

Figs. 3A-B, 4A, 6, 8

Moravia convergens Kukalova, 1964:162 (adult).

Occurrence: Lower Permian (Upper Autunian) of Obora, Czechoslovakia

Original: Specimen no. 1/1976 (obverse and reverse), deposited in the Paleontological Institute of Charles University, Prague, Czechoslovakia.

Two fore wings of a young numph are available (actual length $9 \mathrm{~mm}$, estimated full length $10.6 \mathrm{~mm}$, maximum width $3.5 \mathrm{~mm}$ ). In comparison, the length of the adult fore wing is $38 \mathrm{~mm}$ and the 

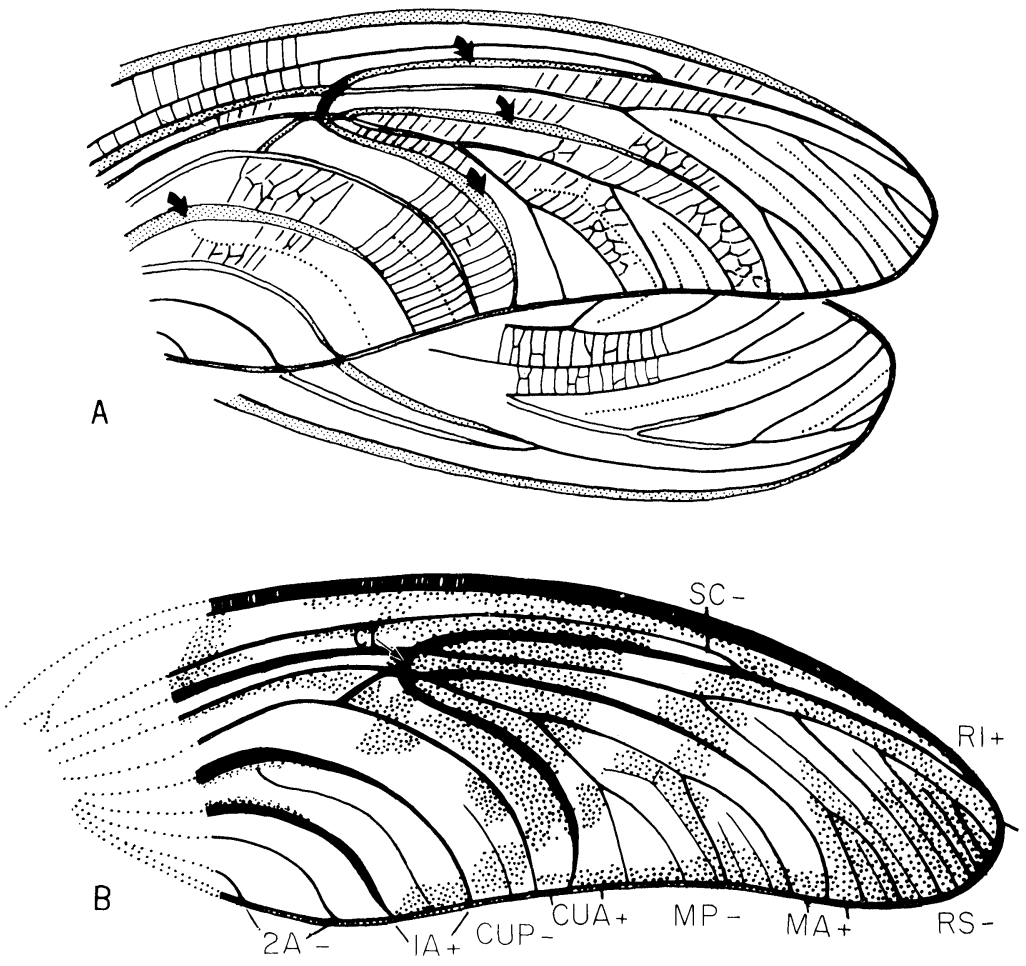

Fig. 3. Moravia convergens, young nymphal fore wings, with distal half curved posteriorly.

A. Actual specimen, arrows pointing to broad veinal blood sinuses.

B. Reconstructed wing pad with color pattern.

Lower Permian of Czechoslovakia. Original.

width $15 \mathrm{~mm}$ (Kukalova, 1964). The wings are not part of a shed cuticle, but are of a partially decomposed and redeposited dead nymph. The outlines of the next instar wings are clearly indicated inside the wing pads.

Several features of the Moravia convergens nymph are notably different from the characters common to all Recent pterygote nymphs and are as follows: 1) The venation is fully formed, corrugated, and cuticularized. In Recent nymphs the tubular venation 
is never present, because it is secreted only during metamorphosis, shortly before the emergence of the adult or subadult. The faint ridges which indicate a simplified venation pattern on Recent nymphal wing pads are not functional veins but are residual surface structures. 2) The venation is identical with that of the adult wings. In Recent nymphs the pattern of blood channels (lacunae) which precede the veins usually approaches the pattern of adult venation only in the terminal nymphal instars. 3) The wing pads are freely articulated. In the Moravia convergens nymph the free attachment is indirectly proven through their easy release from the body after decomposition. In Recent nymphs, the wing pads early in development always become more or less fused together with the lateral margin of the terga, thus simulating continuous, lateral outgrowths.

As noted by Carpenter and Richardson (1969), the nymphs of Megasecoptera and Palaeodictyoptera were probably terrestrial. Equipped with identical mouthparts, they shared with the adults the same food and probably the same arboreal habitat. This finds support in the strongly cuticularized wing pads of Moravia convergens, armored with numerous, protruding tubercles (fig. 6). The most probable function of the tubercles is protection from abrasion. However, later in development, the cuticularized surface of the wing pads becomes thinner with an increase in size so that the subimaginal pre-adults have completely membranous wings (figs. 1, 7). The same process of thinning was observed in Paleozoic Neoptera (Protorthoptera) by Sharov (1957) and is common in Recent insects.

The wing venation of the $M$. convergens nymph has many adult characters: the tubular, corrugated venation; a well developed cross venation; recognizable intercalary sectors; and a distinct color pattern of oblique, irregular dark stripes (figs. 3, 6, 8). The prominent tubercles are restricted to young nymphs, and each carries a single hair or seta. These are arranged in rows on all veins as well as on the entire surface (fig. 6). The most notable nymphal character is the difference in the width between the convex and concave branches of the same vein-pairs. Thus, R1, MA, CuA, and both branches of 1A are conspicuously broad, much broader than their concave partners Rs, MP, CuP, and branches of $2 \mathrm{~A}$ (figs. 3, 8). The veins are widened into broad vein-sinuses, as in some modern insects, i.e., the Embioptera. Since the present specimen is the obverse and reverse of the upper wing surface it is not known 

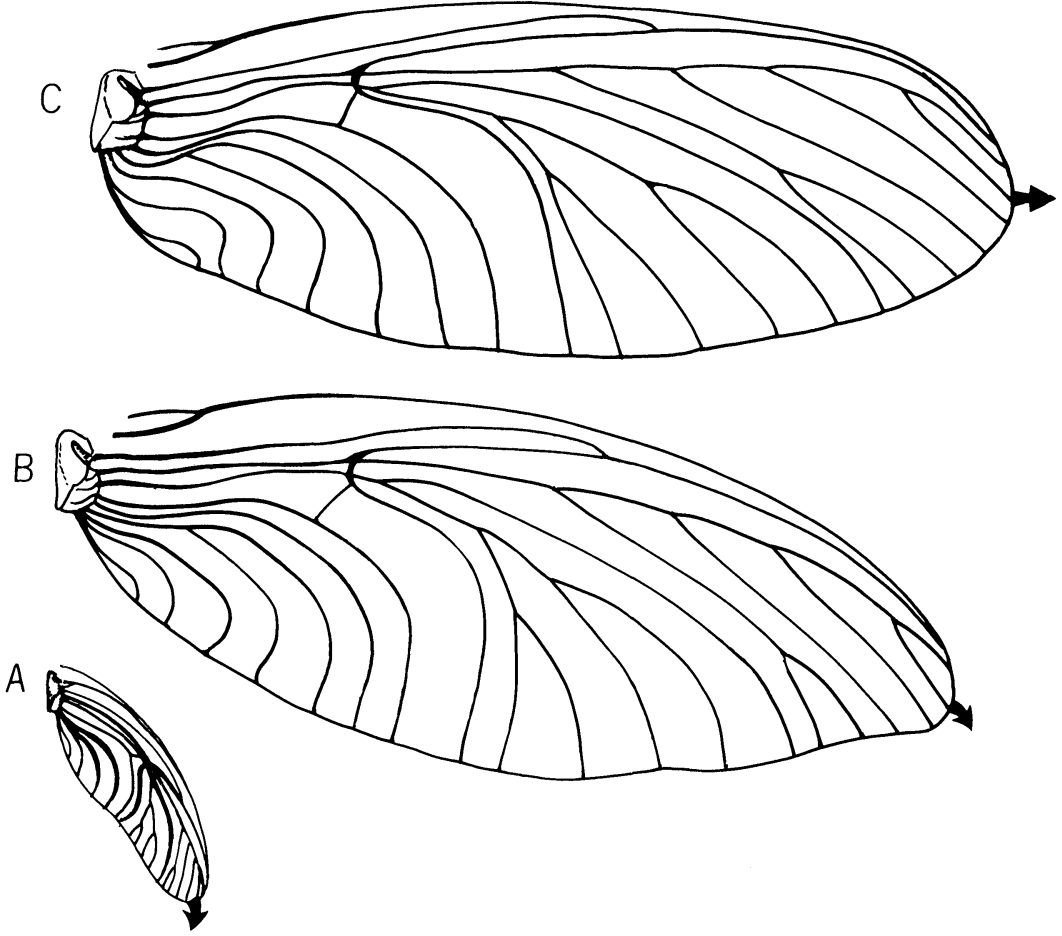

Fig. 4. Stages in the development of the fore wing in Moravia convergens showing changes in the longitudinal axis. A, Very young nymph; B, subimago; C, adult. Lower Permian of Czechoslovakia. Original.

whether or not the concave veins were symmetrically as broad on the lower wing surface. It should be noted that the venation of the adult wings does not show any sign of the presence of vein-blood sinuses. 


\section{Moravia convergens Kukalova, subimago}

Figs. 1, 4B, 7

Occurrence: Lower Permian (Upper Autunian) of Obora, Czechoslovakia.

Original: Specimen no. 2/1976 (obverse and reverse), deposited in the Paleontological Institute of Charles University, Prague, Czechoslovakia.

The fore wing has venation identical to that of the adult (Kukalova, 1964, fig. 2) (fig. 4A), as well as almost identical dimensions (length $36 \mathrm{~mm}$, width $15 \mathrm{~mm}$ ). The subimaginal characters known in Recent mayflies, such as the opaque wing membrane and marginal hairs, could not be observed because they would be lost in the fossilization process. The subimago is distinguished from the adult by the latero-posteriorly curved wing tip. Thus, if the proximal part of the wing axis is set parallel to that of the adult fore wing, the entire anterior margin of the subimago appears to be much more convexly curved (fig. 1). However, this position of the wing is not natural, since in the living insect the wing axis in subimagoes was directed somewhat obliquely backwards as in figs. 4B-C. Because of the curved tip, the subadult wings are distinctly narrower in the apical part than the adult wings. Otherwise, there is no noticeable difference in the pteralia membrane (fig. 7), reticulation, or venation which lies outside the range of individual variation (figs. 1, 4).

The overall similarity in venation and size of the subimaginal and adult wings of Moravia convergens is the proof that the development was gradual and marked by only a series of moultings as in apterygotes. The number of winged subimagoes was probably more than one, judging from data on the related Megasecoptera (Kukalova-Peck, 1974).

\section{Carrizopteryx Kukalova-Peck, n. g.}

Type species: Carrizopteryx arroyo, n. sp., Late Pennsylvanian (Virgilian) of New Mexico. The genus is monobasic and founded on the venation of a single hind wing.

Description. Hind wing: membranous, triangular, very broad in proximal half; subcostal area small; anterior margin slightly concave. Postcostal vein short; Sc terminating on R1 at mid-wing; the stems of $\mathrm{R}$ and $\mathrm{M}$ fused; flat, ribbon-like stem of $\mathrm{Cu}$ adjoining the $\mathrm{R}+\mathrm{M}$ stem; $\mathrm{R}, \mathrm{M}+\mathrm{CuA}$ and $\mathrm{CuP}$ substitute a cuticular thickening of other calvertiellids by radiating from a single spot, at about the first quarter of the wing length; Rs originating shortly beyond the 
"radiating spot," giving rise to 5 main branches, the first of them forked; $M$ diverging immediately beyond the spot of radiation from $\mathrm{CuA}$, and soon forking; MA simple; MP with 4 terminal branches; $\mathrm{Cu}$ dividing at the radiating spot into $\mathrm{CuA}$ and $\mathrm{CuP} ; \mathrm{CuA}$ simple, close and parallel to the proximal branch of MP and to $\mathrm{CuP} ; \mathrm{CuP}$ also simple, either close to or fused with $1 \mathrm{~A}$ posteriorly; anal veins sometimes formed, not curved distinctly backwards, not regular; $1 \mathrm{~A}$ with 2 principal branches, $2 \mathrm{~A}$ with 4 principal branches. Reticulation not very dense, somewhat irregular; intercalated sectors short, irregular. Color pattern of irregular, dark, oblique stripes. Anal brace almost straight, crossing obliquely basal anal area from the posterior margin to the stem of $\mathrm{R}+\mathrm{M}+\mathrm{Cu}$.

Etymology. The generic name is derived from the type locality, Carrizo Arroyo, New Mexico, and pteryx (Greek for wing).

Discussion. Carrizopteryx is the oldest calvertiellid genus and the only one known from the Upper Carboniferous. Its venation is more primitive than that of Lower Permian Moraviptera, Moravia, and Calvertiella in the following features: the anal veins do not differ from other less advanced Palaeodictyoptera; they are branched and lack the parallel regular arrangement and sickle-like curvature typical of the more advanced calvertiellids; the transverse, prominent, cuticular thickening of more specialized calvertiellids is replaced only by a simple contact of the veins at one terminal spot, from which the veins $\mathrm{R}, \mathrm{M}+\mathrm{CuA}$, and $\mathrm{CuP}$ radiate. The fork of MP is relatively narrow and oriented more obliquely to-

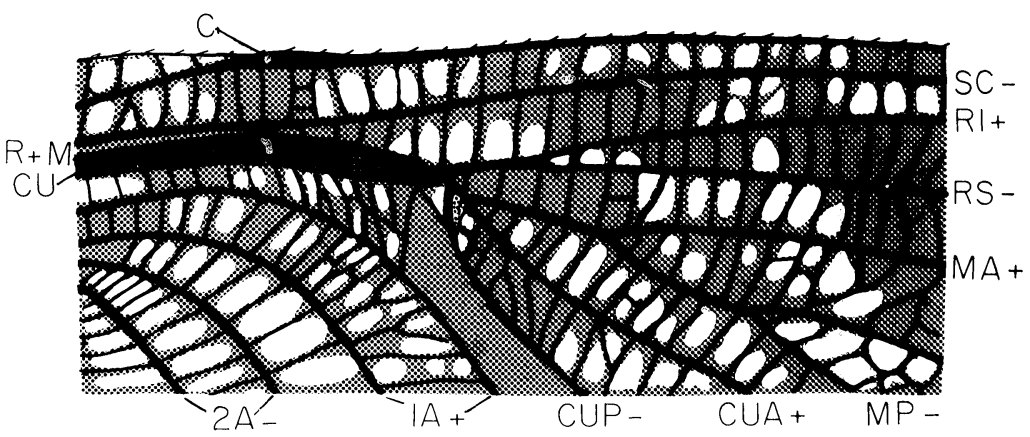

Fig. 5. Carrizopteryx arroyo, n. sp., portion of the hind wing showing ribbon-like cubital stem and color pattern. Late Upper Carboniferous of New Mexico. Original. 
wards the posterior margin. The areas between MP-CuA-CuP are almost of equal shape and width and much less specialized than in other calvertiellids.

However, Carrizopteryx has a very specialized feature of its own, which is not present in either of the other calvertiellids: the fused stem of $\mathrm{R}+\mathrm{M}$ with the adjoined ribbon-like $\mathrm{Cu}$ stem (figs. 2, 5). Fused stems of $\mathrm{R}+\mathrm{M}$ repeatedly occur within the Pterygota but the combination of $\mathrm{R}+\mathrm{M}$ and a ribbon-like $\mathrm{Cu}$ stem is rare, atypical for Palaeodictyoptera but typical for elmoid Diaphanopterodea (a specialized group of Paleoptera able to flex their wings backwards over the abdomen while resting). However, this morphological coincidence does not express any close phylogenetic ties and is probably deeply rooted in the common genetic makeup of the Paleoptera.

Carrizopteryx arroyo Kukalova-Peck, n. sp.

Figs. 2, 5

Holotype: no. 3157 (hind wing, obverse and reverse), deposited in collections of the Department of Geology, University of New Mexico, Albuquerque, New Mexico.

This species is based upon a well preserved adult hind wing, with the very base and the middle part of the posterior margin missing, and with a color pattern of irregular oblique stripes. The fusion of $\mathrm{CuP}$ and $1 \mathrm{~A}$ posteriorly, as well as the branching of the anal veins, may be individually variable.

Description. Hind wing: length $31 \mathrm{~mm}$; width $14.2 \mathrm{~mm}$. Posterior margin with slight undulation between $1 \mathrm{~A}$ and $\mathrm{CuP}$ and $2 \mathrm{~A}$; first branch of $\mathrm{Rs}$ originating at mid-wing; $\mathrm{MP}$ with two relatively narrow forks; proximal branch of MP, CuA and CuP equally distant from each other; anal veins undulating lengthwise, with a slight tendency toward a sickle-like curvature at their very tips.

Etymology. The specific name is a noun in apposition, and refers to Carrizo Arroyo, the type locality.

The Evolution of Wing Characters in the Calvertiellidae

As presently known, the occurrences of Calvertiellidae are scattered across the western half of the Northern Upper Paleozoic continent, and span a time from late Pennsylvanian (Virgilian) to late Permian (Leonard). In spite of the fact that the available ma- 

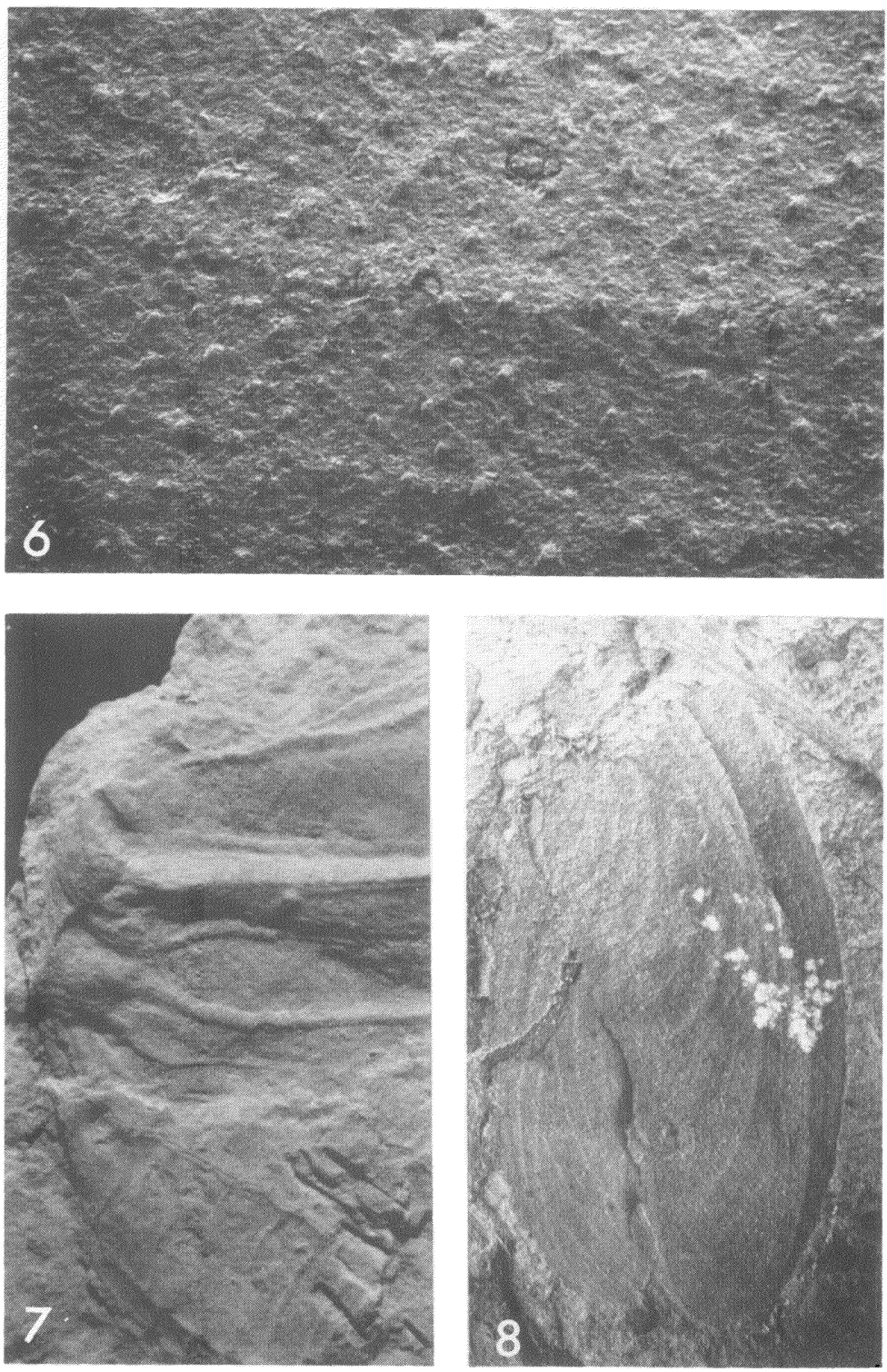
terial in the field of Paleozoic insects is relatively "rich" it is obviously not sufficient for any reliable conclusions to be drawn from it. However, some hypotheses can be suggested as possible.

The calvertiellids developed from an ancestor which closely resembled Carrizopteryx in venation, but had separated stems of $\mathrm{R}, \mathrm{M}$, and $\mathrm{Cu}$, and narrower wings. The characters of venation which appear to be potentially useful for stratigraphy are the following: the richness of ramification (the branching of venation is diminished in advanced forms); the density and regularity of reticulation (reticulation becomes larger and more cross veins are present in advanced forms); and the special features of the anal area (anal veins become simple and curved sickle-like in advanced forms). All these features developed in succession and progressively from the oldest genus, Carrizopteryx, to the youngest genus, Calvertiella.

The characters which seem to be independently variable and under the influence of mosaic evolution or of "latent homology" (sensu de Beer, 1971), are the following: the fusion and the form of the vein-stems; the degree of "discarding of the CuA" (i.e., how close $\mathrm{CuA}$ is shifted towards MP to function as a joined double vein). Also, the relative width of the wings is apparently independent of the stratigraphical occurrence, since Carrizopteryx (Virgilian) and then again Moravia (Upper Autunian) are conspicuously broad, while Moraviptera (Lower Autunian) and then again Calvertiella (Leonard) are moderately broad.

With the scanty information available, a more precise suggestion of the age of the strata in Carrizo Arroyo would be premature. All that can be said at present is that the general character of the venation of Carrizopteryx is the most primitive among the Calvertiellidae and that this may be due to an occurrence in strata older than the base of the Lower Permian.

Figures 6-8 (opposite).

Fig. 6. Moravia convergens, young nymph; SEM photo micrograph of the wing surface with prominent tubercles. Lower Permian of Czechoslovakia. Fig. 7. Moravia convergens, subimaginal fore wing base with pteralia of palaeodictyopteroid type and the anal brace. Lower Permian of Czechoslovakia. Fig. 8. Moravia convergens, SEM photo micrograph. Lower Permian of Czechoslovakia. 


\section{Acknowledgements}

Our field research was partially supported by Canadian National Research Council grants to both of us, and a Geological Society of America grant io JK-P. Olga and Hana Kukal and Bob Peck worked long and hard in an excavation. Dr. Barry Kues generously gave his time and loaned specimens from Carrizo Arroyo. Dr. Sergius H. Mamay, Dr. Stuart A. Northrop, Mr. T. J. Kinney and Mr. Ed. Kinney are thanked for graciously providing information on geology and localities. Karel and Anna Havlata have given their time and energy in continuing to work on the Obora locality in Czechoslovakia, and found the material described here. Drs. Kenneth Hooper and John Moore, Department of Geology, Carleton University, have helped with research space and encouragement. We are very obliged to Professor Frank M. Carpenter (Harvard University, Cambridge, Mass.) for reading the manuscript.

\section{Literature Cited}

Carpenter, F. M.

1943. Studies on Carboniferous Insects from Commentry, France. Part 1. Bull. Geol. Soc. Amer. 54: 527-554.

1970. Fossil Insects from New Mexico. Psyche 77: 400-412.

Carpenter, F. M. and E. S. Richardson, Jr.

1969. Megasecopterous nymphs in Pennsylvanian concretions from Illinois. Psyche 75: 295-309.

DE BEER, G.

1971. Homology, an unsolved problem. part 7, in J. J. Head and O. E. Lowenstein, eds., Readings in Genetics and Evolution, Oxford Univ. Press, London.

Kukalova, J.

1955. Permoedischia n. g. (Protorthoptera) and Moraviptera n. g. (Palaeodictyoptera) from the Moravian Permian. Sbornik UUG 21: 541-575.

1964. Review of the Calvertiellidae, with description of a new genus from Permian strata of Moravia (Palaeodictyoptera). Psyche 71: 153-168.

1968. Permian Mayfly nymphs. Psyche 75: 310-327.

Kukalova-Peck, J.

1974. Pteralia of the Paleozoic insect orders Palaeodictyoptera, Megasecoptera, and Diaphanopterodea (Paleoptera). Psyche 81: 416-430.

1975. Megasecoptera from the Lower Permian of Moravia. Psyche, 82: 1-19. Sharov, A. G.

1957. Types of metamorphosis of insects and their mutual relations (from comparative ontogenetic and paleontologic data). Ent. Obozr. 36: 569-576.

1966. Basic Arthropodan Stock. Pergamon Press, London. 
1971. Morphological features and the way of life of Palaeodictyoptera. Dokl. 24, tschtenii pam. N.A. Cholodkowskogo. Akad. Nauk SSSR, Moscow: 49-63.

Tillyard, R. J.

1925. Kansas Permian Insects. Part 5. The orders Protodonata and Odonata. Amer. Jr. Sci. 10: 41-73.

Woorton, R. J.

1972. Nymphs of Palaeodictyoptera (Insecta) from the Westphalian of England. Palaeontology 15: 662-675. 

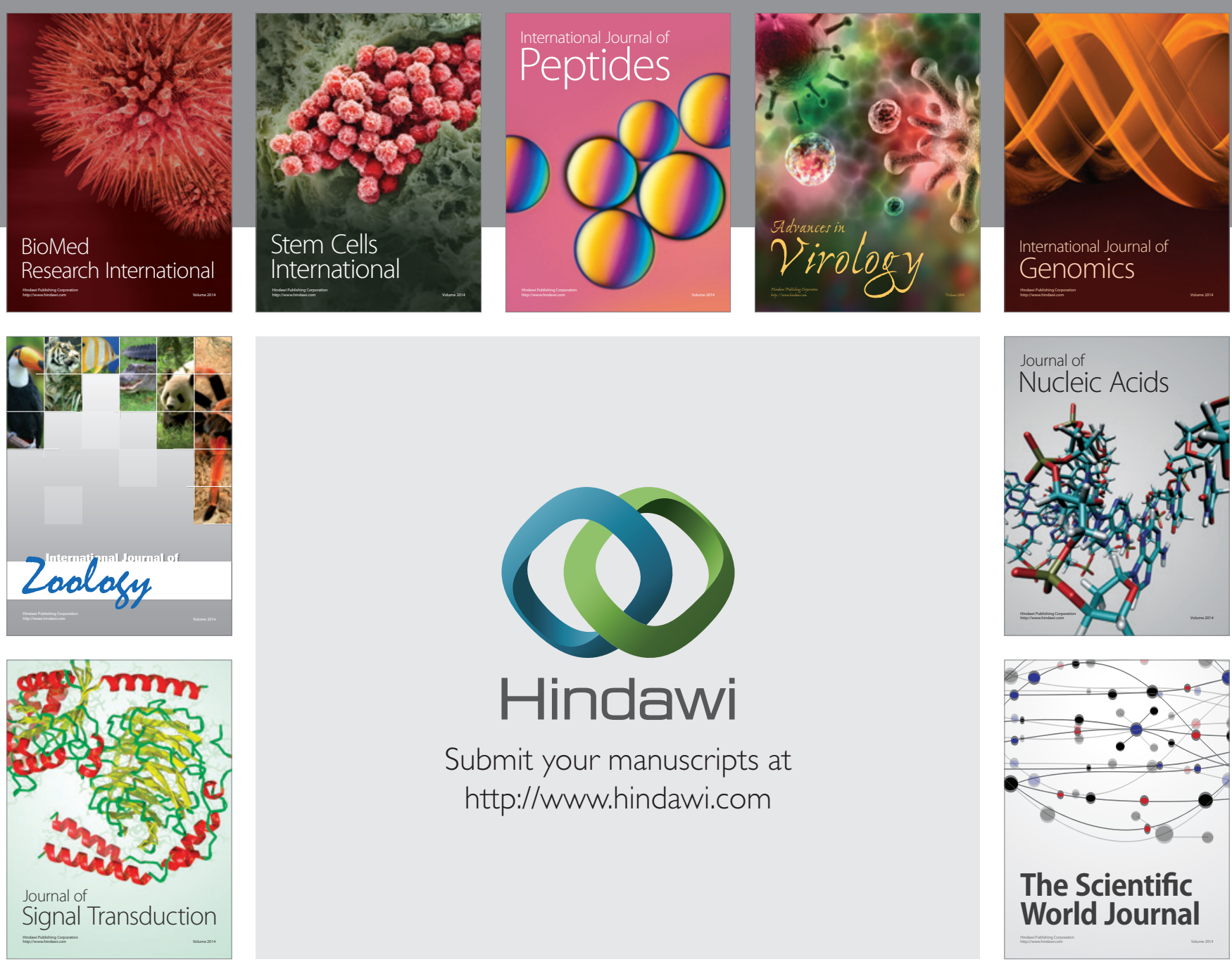

Submit your manuscripts at

http://www.hindawi.com
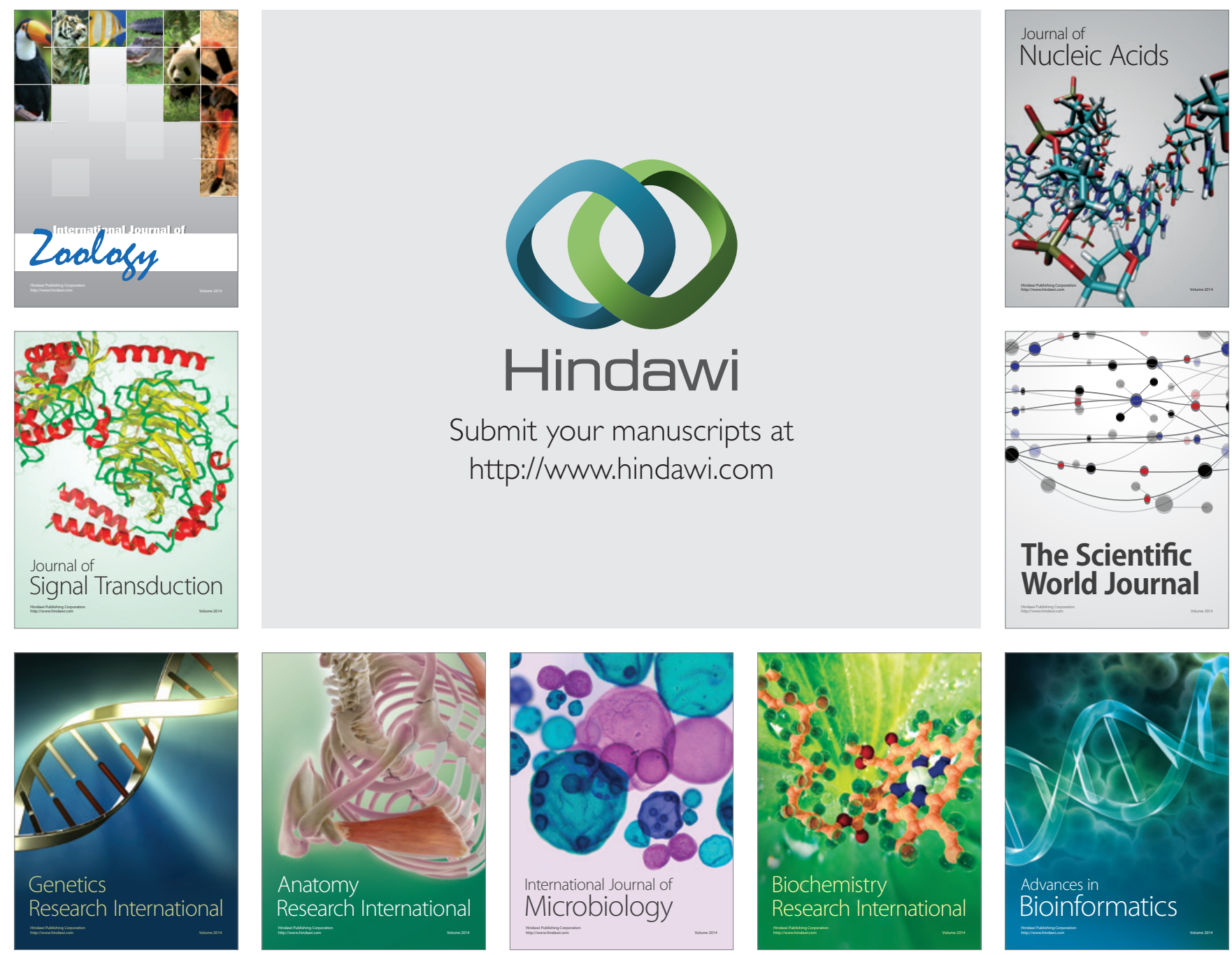

The Scientific World Journal
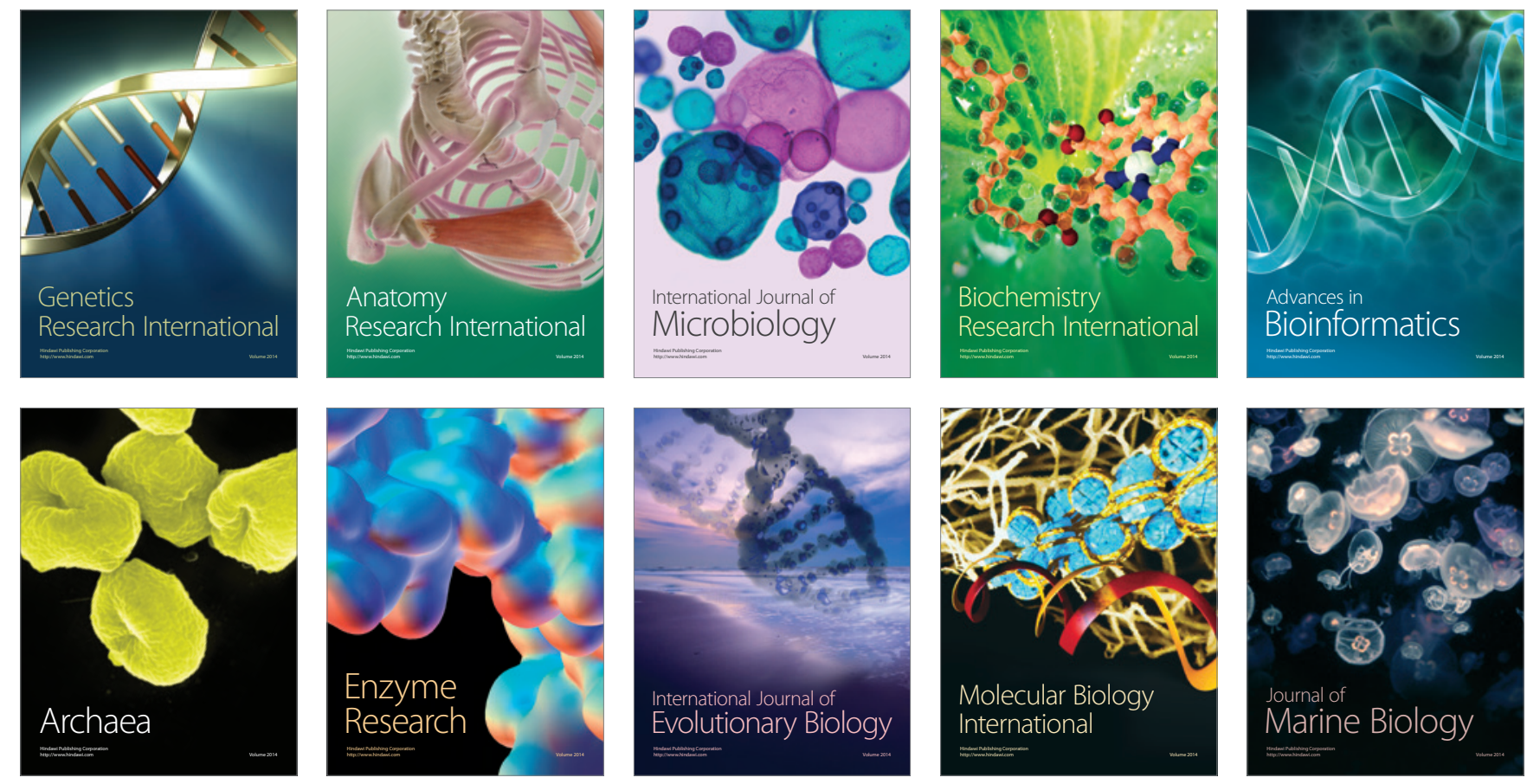